\title{
Rhodium Assisted C-H Activation of Benzaldehyde Thiosemicarbazones and Their Oxidation via Activation of Molecular Oxygen
}

\author{
Rama Acharyya, ${ }^{\dagger}$ Swati Dutta, ${ }^{\dagger}$ Falguni Basuli, ${ }^{\dagger}$ Shie-Ming Peng, ${ }^{\ddagger}$ Gene-Hsiang Lee, ${ }^{\ddagger}$ \\ Larry R. Falvello, ${ }^{\S}$ and Samaresh Bhattacharya ${ }^{*, \dagger}$ \\ Department of Chemistry, Inorganic Chemistry Section, Jadavpur University, Kolkata - 700032 , \\ India, Department of Chemistry, National Taiwan University, Taipei, Taiwan, R.O.C., and \\ Department of Inorganic Chemistry, Faculty of Science, University of Zaragoza, E-50009 \\ Zaragoza, Spain
}

Received April 5, 2005

\begin{abstract}
The benzaldehyde thiosemicarbazones are found to undergo oxidation at the sulfur center upon reaction with $\left[\mathrm{Rh}\left(\mathrm{PPh}_{3}\right)_{3} \mathrm{Cl}\right]$ in refluxing ethanol in the presence of a base $\left(\mathrm{NEt}_{3}\right)$. A group of organorhodium complexes are obtained from such reactions, in which the oxidized thiosemicarbazones are coordinated to rhodium as tridentate CNS donors, along with two triphenylphosphines and a hydride. From the reaction with para-nitrobenzaldehyde thiosemicarbazone, a second organometallic complex is obtained, in which the thiosemicarbazone is coordinated to rhodium as a tridentate CNS donor, along with two triphenylphosphines and a hydride. Reaction of the benzaldehyde thiosemicarbazones with $\left[\mathrm{Rh}\left(\mathrm{PPh}_{3}\right)_{3} \mathrm{Cl}\right]$ in refluxing ethanol in the absence of $\mathrm{NEt}_{3}$ affords another group of organorhodium complexes, in which the thiosemicarbazones are coordinated to rhodium as tridentate CNS donors, along with two triphenylphosphines and a chloride. Structures of representative complexes of each type of complexes have been determined by X-ray crystallography. In all of the complexes, the two $\mathrm{PPh}_{3}$ ligands are trans. All of the complexes show intense MLCT transitions in the visible region. Cyclic voltammetry on these complexes shows a $\mathrm{Rh}(\mathrm{III})-\mathrm{Rh}$ (IV) oxidation on the positive side of SCE. Redox responses of the coordinated thiosemicarbazones are also displayed by all of the complexes.
\end{abstract}

\section{Introduction}

There is considerable current interest in the chemistry of transition metal complexes of the thiosemicarbazone ligands, primarily because of their bioinorganic relevance. ${ }^{1}$ The complexes in this class are of particular importance because of their potentially beneficial biological (viz., antibacterial, antimalarial, antiviral, and antitumor) activities. ${ }^{2}$ However, we have been interested in the chemistry of thiosemicarbazone complexes of the platinum metals particularly because of the variable coordination modes displayed by such ligands in these complexes. ${ }^{3}$ For the present study, we have chosen a group of benzaldehyde thiosemicarbazones (1) as the

* To whom correspondence should be addressed. E-mail: samaresh_b@ hotmail.com.

Jadavpur University.

$\doteqdot$ National Taiwan University.

$\S$ University of Zaragoza.

(1) (a) West, D. X.; Liberta, A. E.; Padhye, S. B.; Chikate, R. C.; Sonawane, P. B.; Kumbhar, A. S.; Yerande, R. G. Coord. Chem. Rev. 1993, 123, 49. (b) West, D. X.; Padhye, S. B.; Sonawane, P. B. Struct. Bonding 1992, 76, 1. (c) Haiduc, I.; Silvestru, C. Coord. Chem. Rev. 1990, 99, 253. (d) Padhye, S. B.; Kaffman, G. B. Coord. Chem. Rev. 1985, 63, 127. (e) Campbell, M. J. M. Coord. Chem. Rev. 1975, 15, 279.

1252 Inorganic Chemistry, Vol. 45, №. 3, 2006 ligands and rhodium as the metal. It might be relevant to mention here that, although the chemistry of thiosemicarbazone complexes of many transition metals has been extensively studied, ${ }^{1}$ that of rhodium appears to have
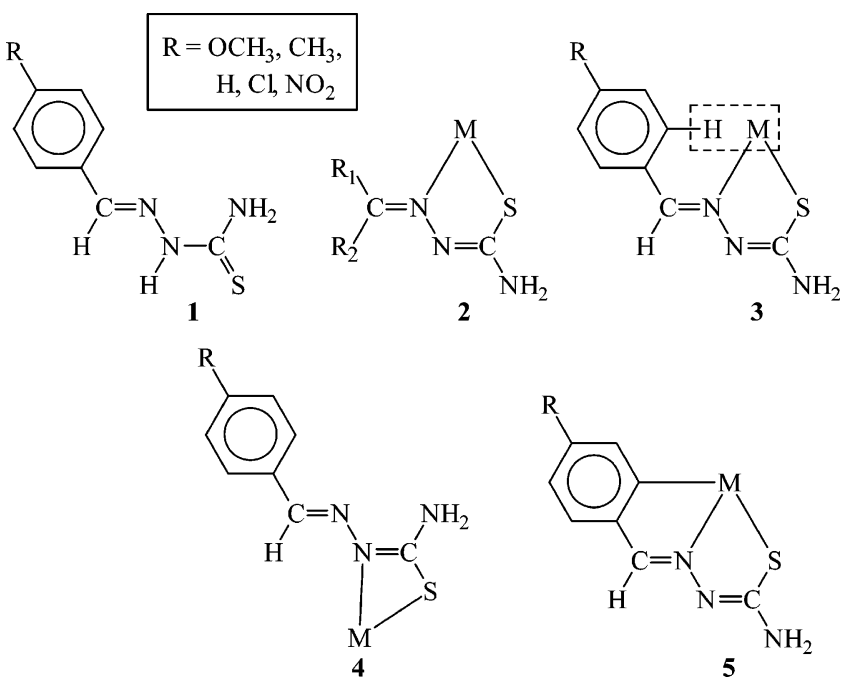

10.1021/ic050505w CCC: $\$ 33.50$

(C) 2006 American Chemical Society Published on Web 01/04/2006 


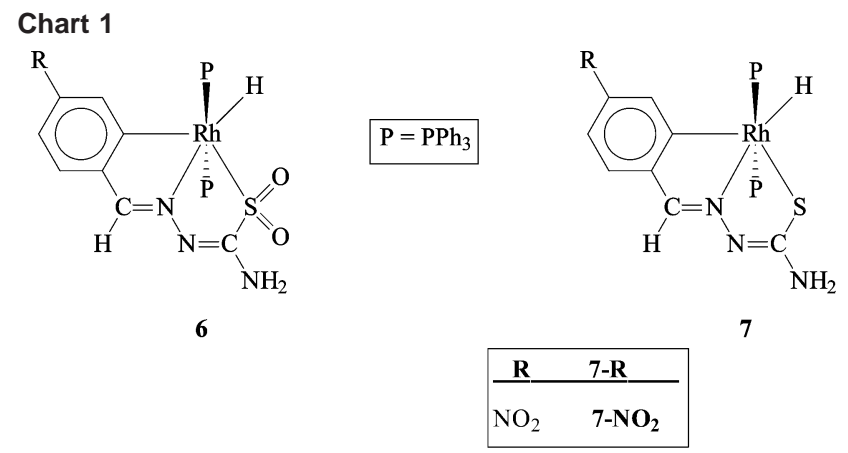

\begin{tabular}{|lll|}
\hline $\mathbf{R}$ & $\mathbf{6 - R}$ & $\mathbf{8 - R}$ \\
\hline $\mathrm{OCH}_{3}$ & $\mathbf{6 - O C H}$ & $\mathbf{8 - O C H}$ \\
$\mathrm{CH}_{3}$ & $\mathbf{6 - C H}$ & $\mathbf{8}-\mathbf{C H}_{3}$ \\
$\mathrm{H}$ & $\mathbf{6 - H}$ & $\mathbf{8}-\mathbf{H}$ \\
$\mathrm{Cl}$ & $\mathbf{6 - C l}$ & $\mathbf{8 - C l}$ \\
$\mathrm{NO}_{2}$ & $\mathbf{6 - N O}$ & $\mathbf{8}-\mathbf{N O}_{\mathbf{2}}$ \\
\hline
\end{tabular}

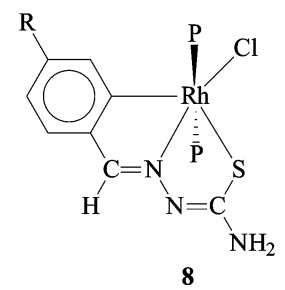

remained almost unexplored. ${ }^{4}$ Although the thiosemicarbazones are usually expected to coordinate metal ions, via dissociation of the hydrazinic proton, as bidentate N,S donors forming a five-membered chelate ring (2), we have observed that formation of such a ring depends primarily on the size of $\mathrm{R}_{1}{ }^{3 \mathrm{c}}$ Only if $\mathrm{R}_{1}$ is fairly small (e.g., $\mathrm{R}_{1}=\mathrm{CH}_{3}$ ) formation of a five-membered ring (2) possible, but if $R_{1}$ is relatively large (e.g., $\mathrm{R}_{1}=$ aryl as in ligand $\mathbf{1}$ ), such a ring cannot be formed. The uncoordinated benzaldehyde thiosemicarbazones $\mathbf{1}$ have the geometry as shown in $\mathbf{1},{ }^{3 \mathrm{c}}$ and if such a fivemembered ring has to form keeping the conformation about the $\mathrm{C}=\mathrm{N}$ bond in $\mathbf{1}$ intact, the phenyl ring of the thiosemicarbazone ligand comes in contact with the metal center, and thus a steric hindrance develops between them (3). It should be mentioned in this context that we were unable to find a single example of a structurally characterized complex of the benzaldehyde thiosemicarbazones 1 where the thi-

(2) (a) Jouad, E. M.; Thanh, X. D.; Bouet, G.; Bonneau, S.; Khan, M. A Anticancer Res. 2002, 22, 1713. (b) Ferrari, M. B.; Bisceglie, F.; Pelosi, G.; Sassi, M.; Tarasconi, P.; Cornia, M.; Capacchi, S.; Albertini, R.; Pinelli, S. J. Inorg. Biochem. 2002, 90, 113. (c) Cowly, A. R.; Dilworth, J. R.; Donnely, P. S.; Labisbal, E.; Sousa, A. J. Am. Chem. Soc. 2002, 124, 5270. (d) Maurer, R. I.; Blower, P. J.; Dilworth, J. R.; Reynolds, C. A.; Zheng, Y.; Mullen, G. E. D. J. Med. Chem. 2002, 45, 1420. (e) Patole, J.; Dutta, S.; Padhye, S.; Sinn, E. Inorg. Cmim. Acta 2001, 318, 207. (f) Iakovidou, Z.; Papageorgiou, A.; Demertzis, M. A.; Mioglou, E.; Mourelatos, D.; Kotsis, A.; Yadav, P. N.; KovalaDemertzi, D. Anticancer Drugs 2001, 12, 65. (g) Kovala-Demertzi, D.; Miller, J. R.; Kourkoumelis, N.; Hadjikakou, S. K.; Demertzis, M. A. Polyhedron 1999, 18, 1005. (h) Miller, M. C., III; Stineman, C. N.; Vance, J. R.; West, D. X.; Hall, I. H. Anticancer Res. 1998 18, 4131. (i) Papageorgiou, A.; Iakovidou, Z.; Mourelatos, D.; Mioglou, E.; Boutis, L.; Kotsis, A.; Kovala-Demertzi, D.; Domopoulou, D. X.; Demertzis, M. A. Anticancer Res. 1997, 17, 247. (j) Dimmock, J. R.; Puthucode, R. N.; Smith, J. M.; Hetherington, M.; Quail, J. W.; Pugazhenthi, U.; Lechler, J.; Stables, J. P. J. Med. Chem. 1996, 39, 3984.

(3) (a) Dutta, S.; Basuli, F.; Peng, S. M.; Lee, G. H.; Bhattacharya, S. New J. Chem. 2002, 26, 1607. (b) Pal, I.; Basuli, F.; Mak, T. C. W.; Bhattacharya, S. Angew. Chem., Int. Ed. 2001, 40, 2923. (c) Basuli, F.; Peng, S. M.; Bhattacharya, S. Inorg. Chem. 2000, 39, 1120. (d) Basuli, F.; Ruf, M.; Pierpont, C. G.; Bhattacharya, S. Inorg. Chem. 1998, 39, 6113. (e) Basuli, F.; Peng, S. M.; Bhattacharya, S. Inorg. Chem. 1997, 36, 5645 .

(4) (a) Mukkanti, K.; Singh, R. P. Trans. Met. Chem. 1987, 12, 299. (b) Popa et al. Lucr. Conf. Nat. Chim. Anal. 3rd 1971, 3, 197. osemicarbazone is coordinated as in $\mathbf{3}$. Formation of a stable five-membered ring by the benzaldehyde thiosemicarbazones can only take place via a conformational change about the $\mathrm{C}=\mathrm{N}$ bond in $\mathbf{1}$, which requires a restricted rotation about a double bond..$^{5}$ Being unable to form a five-membered chelate ring, the benzaldehyde thiosemicarbazones $\mathbf{1}$ are observed to bind to the metal center as bidentate N,S donors forming a rather unusual four-membered chelate ring (4). ${ }^{3 c-e}$ Even though formation of five-membered chelate ring $\mathbf{3}$ by the benzaldehyde thiosemicarbazones $\mathbf{1}$ has been accepted to be impossible, the proximity of the phenyl ring to the metal center in $\mathbf{3}$ points to the possibility of its orthometalation (5) via $\mathrm{C}-\mathrm{H}$ activation. Transition-metal-mediated $\mathrm{C}-\mathrm{H}$ activation of organic molecules is of significant contemporary importance, with particular reference to chemical transformations of organic molecules. ${ }^{6}$ Such reactions often proceed via a $\mathrm{C}-\mathrm{H}$ activation step leading to the formation of organometallic complexes as reactive intermediates, which then undergo further reactions to yield the desired product. With the intention of inducing coordination mode $\mathbf{5}$ in the benzaldehyde thiosemicarbazone ligands $\mathbf{1}$, their reaction has been carried out with the Wilkinson's catalyst, viz., [Rh$\left.\left(\mathrm{PPh}_{3}\right)_{3} \mathrm{Cl}\right]$. We selected this particular rhodium starting material because of its demonstrated ability to accommodate a tridentate ligand via oxidative addition ${ }^{3 \mathrm{a}, 7}$ and, more importantly, its efficiency in successfully mediating $\mathrm{C}-\mathrm{H}$ activation of organic molecules..$^{\text {aa, b }}$ This simple strategy has indeed worked nicely, affording organorhodium complexes of different types, and the chemistry of these complexes is reported in this paper with special reference to their synthesis, structure, and electrochemical properties.

\section{Experimental Section}

Materials. Rhodium trichloride was obtained from Arora Matthey, Kolkata, India. All other chemicals and solvents were reagentgrade commercial materials and were used as received. $\left[\mathrm{Rh}\left(\mathrm{PPh}_{3}\right)_{3^{-}}\right.$ $\mathrm{Cl}$ ] was synthesized following a reported procedure. ${ }^{8}$ The benzaldehyde thiosemicarbazones $\mathbf{1}$ were prepared by reacting

(5) (a) Tian, Y. P.; Duan, C. Y.; Lu, Z. L.; You, X. Z.; Fun, H. K.; Sivakumar, K. Polyhedron 1996, 15, 2263. (b) Sinha, S.; Acharyya, R.; Basuli, F.; Peng, S. M.; Bhattacharya, S. Jadavpur University, Kolkata, India, and Taipei, Taiwan, ROC, 2005, unpublished results.

(6) (a) Crabtree, R. H. J. Chem. Soc., Dalton Trans. 2003, 3985. (b) Pamplin, C. B.; Legzdins, P. Acc. Chem. Res. 2003, 36, 223. (c) Ritleng, V.; Sirlin, C.; Pfeffer, M. Chem. Rev. 2002, 102, 1731. (d) Slugovc, C.; Padilla-Martnez, I.; Sirol, S.; Carmona, E. Coord. Chem. Rev. 2001, 213, 129. (e) Jia, C.; Kitamura, T.; Fujiwara, Y. Acc. Chem. Res. 2001, 34, 633. (f) Tsuji, J. Transition Metal Reagents and Catalysts; Wiley-VCH: Weinheim, Germany, 2000. (g) Beller, M.; Bolm, C.; Eds. Transition Metals for Organic Synthesis, 1-2; WileyVCH: Weinheim, Germany, 1998. (h) Hegedus, L. S. Coord. Chem. Rev. 1998, 168, 49. (i) Cornils, B.; Hermann, W. A.; Eds. Applied Homogeneous Catalysis with Organometallic Compounds: A Comprehensive Handbook in Two Volumes; VCH: Weinheim, Germany, 1996. (j) Liebeskind, L. S.; Ed. Advances in Metal-Organic Chemistry; Jai Press: Greenwich, CT, 1996. (k) Abel, E.; Stone, F. G. A. Wilkinson, G.; Eds. Comprehensive Organometallic Chemistry; Pergamon Press: Oxford, U.K., 1995, 12. (1) Hegedus, L. S. Transition Metals in the Synthesis of Complex Organic Molecules; University Science Books: Mill Valley, CA, 1994.

(7) (a) Pal, I.; Dutta, S.; Basuli, F.; Goverdhan, S.; Peng, S. M.; Lee, G. H.; Bhattacharya, S. Inorg. Chem. 2003, 42, 4338. (b) Dutta, S.; Peng, S. M.; Bhattacharya, S. J. Chem. Soc., Dalton Trans. 2000, 4623. (c) Dutta, S.; Peng, S. M.; Bhattacharya, S. Inorg. Chem. 2000, 39, 2231.

(8) Osborn, J. A.; Wilkinson, G. Inorg. Synth. 1967, 10, 67. 
equimolar amounts of thiosemicarbazide with the respective parasubstituted benzaldehyde in a 1:1 ethanol/water mixture. Purification of dichloromethane and acetonitrile and preparation of tetrabutylammonium perchlorate (TBAP) for electrochemical work were performed as before. ${ }^{9}$

Preparations of Complexes. (i) 6-OCH . para-Methoxybenzaldehyde thiosemicarbazone $(25 \mathrm{mg}, 0.11 \mathrm{mmol})$ was dissolved in ethanol $(30 \mathrm{~mL})$, and to it was added triethylamine $(25 \mathrm{mg}, 0.24$ mmol). Then, $\left[\mathrm{Rh}\left(\mathrm{PPh}_{3}\right)_{3} \mathrm{Cl}\right](100 \mathrm{mg}, 0.11 \mathrm{mmol})$ was added, and the mixture was heated at reflux for $7 \mathrm{~h}$ to yield a deep yellow solution. Evaporation of this solution gave a brownish-yellow solid, which was subjected to purification by thin-layer chromatography on a silica plate. With 1:1 toluene/acetonitrile as the eluant, a yellow band separated, which was extracted with acetonitrile. Upon evaporation of the acetonitrile extract, $\mathbf{6}-\mathbf{O C H}_{3}$ was obtained as crystalline yellow solid. Yield: $53 \%$. Anal. Calcd for $\mathbf{6}-\mathbf{O C H}_{3}$ : C, 62.29; H, 4.61; N, 4.84. Found: C, 62.33; H, 4.59; N, 4.84. ${ }^{1} \mathrm{H}$ NMR: ${ }^{10}-11.45(\mathrm{t}$, hydride, $J=19.5 \mathrm{~Hz}), 3.35\left(\mathrm{OCH}_{3}\right), 4.27\left(\mathrm{NH}_{2}\right)$, $6.64(\mathrm{~s}, 1 \mathrm{H}), 6.76(\mathrm{~d}, 1 \mathrm{H}, J=8.0 \mathrm{~Hz}), 6.82(\mathrm{~s}, 1 \mathrm{H}), 6.92(\mathrm{~d}, 1 \mathrm{H}$, $J=7.9 \mathrm{~Hz}), 6.94-7.68\left(2 \mathrm{PPh}_{3}\right)$.

(ii) 6- $\mathbf{C H}_{3}$. This complex was prepared by following the same procedure as described above taking para-methylbenzaldehyde thiosemicarbazone instead of para-methoxybenzaldehyde thiosemicarbazone. Yield: $50 \%$. Anal. Calcd for $\mathbf{6}-\mathbf{C H}_{3}$ : C, 63.46; H, 4.70; $\mathrm{N}$, 4.94. Found: C, 63.54; H, 4.71; N, 4.96. ${ }^{1} \mathrm{H}$ NMR: -11.50 (t, hydride, $J=19.0 \mathrm{~Hz}), 1.91\left(\mathrm{CH}_{3}\right), 4.69\left(\mathrm{NH}_{2}\right), 6.28(\mathrm{~s}, 1 \mathrm{H}), 6.33$ $(\mathrm{d}, 1 \mathrm{H}, J=6.0 \mathrm{~Hz}), 6.67(\mathrm{~d}, 1 \mathrm{H}, J=6.1 \mathrm{~Hz}), 6.97(\mathrm{~s}, 1 \mathrm{H}), 7.00-$ $7.79\left(2 \mathrm{PPh}_{3}\right)$.

(iii) 6-H. This complex was prepared by following the same procedure as described above taking benzaldehyde thiosemicarbazone instead of para-methylbenzaldehyde thiosemicarbazone. Yield: 52\%. Anal. Calcd for 6-H: C, 63.09; H, 4.54; N, 5.02. Found: C, 63.12; H, 4.52; N, 5.05. ${ }^{1} \mathrm{H}$ NMR: -11.62 (q, hydride, $J=19.5 \mathrm{~Hz}), 3.64\left(\mathrm{NH}_{2}\right), 6.25(\mathrm{t}, 1 \mathrm{H}, J=6.00 \mathrm{~Hz}), 6.57(\mathrm{t}, 1 \mathrm{H}$, $J=9.00 \mathrm{~Hz}), 6.67(\mathrm{~d}, 1 \mathrm{H}, J=9.0 \mathrm{~Hz}), 7.00(\mathrm{~d}, 1 \mathrm{H}, J=3.48 \mathrm{~Hz})$, $7.12(\mathrm{~s}, 1 \mathrm{H}), 7.19-7.63\left(2 \mathrm{PPh}_{3}\right)$.

(iv) 6-Cl. This complex was prepared by following the same procedure as described above taking para-chlorobenzaldehyde thiosemicarbazone instead of benzaldehyde thiosemicarbazone. The deep yellow solid obtained after reflux was subjected to purification by thin-layer chromatography on a silica plate using 10:1 toluene/ acetonitrile as the eluant. A yellow band separated, which was extracted with acetonitrile. Evaporation of the acetonitrile extract yielded the 6-Cl complex as a yellow solid. Yield: $52 \%$. Anal. Calcd for 6-Cl: C, 60.59; H, 4.25; N, 4.82. Found: C, 60.55; H, 4.30; N, 4.91. ${ }^{1} \mathrm{H}$ NMR: -11.42 (t, hydride, $J=19.3 \mathrm{~Hz}$ ), 4.75 $\left(\mathrm{NH}_{2}\right), 6.43(\mathrm{~s}, 1 \mathrm{H}), 6.51$ (d, 1H, $\left.J=6.9 \mathrm{~Hz}\right), 6.68(\mathrm{~d}, 1 \mathrm{H}, J=6.7$ $\mathrm{Hz}), 6.98(\mathrm{~s}, 1 \mathrm{H}), 7.10-7.72\left(2 \mathrm{PPh}_{3}\right)$.

(v) 6-NO $\mathrm{NO}_{2}$ and 7-NO $\mathrm{N}_{2}$ p para-Nitrobenzaldehyde thiosemicarbazone (24 mg, $0.11 \mathrm{mmol})$ was dissolved in ethanol $(30 \mathrm{~mL})$, and to it was added triethylamine $(25 \mathrm{mg}, 0.24 \mathrm{mmol})$. Then, [Rh$\left.\left(\mathrm{PPh}_{3}\right)_{3} \mathrm{Cl}\right](100 \mathrm{mg}, 0.11 \mathrm{mmol})$ was added, and the mixture was heated at reflux for $7 \mathrm{~h}$ to yield a dark red solution. The solid mass obtained upon evaporation of the red solution was subjected to purification by thin-layer chromatography on a silica plate using 10:1 toluene/acetonitrile as the eluant. Two prominent bands (a pink band and a red band) separated, which were extracted with

(9) (a) Sawyer, D. T.; Roberts, J. L., Jr. Experimental Electrochemistry for Chemists; Wiley: New York, 1974; pp 167-215. (b) Walter, M.; Ramaley, L. Anal. Chem. 1973, 45, 165.

(10) Chemical shifts are given in ppm, and multiplicity of the signals along with the associated coupling constants are given in parentheses. Overlapping signals are marked with an asterisk. acetonitrile. Evaporation of these extracts yielded the 6-NO (Yield: 23\%) and 7- $\mathbf{N O}_{2}$ (Yield: 64\%) complexes, respectively. Anal. Calcd for 6-NO $\mathbf{N O}_{2}$ C, 59.87; H, 4.19; N, 6.35. Found: C, 59.95; H, 4.23; N, 6.38. ${ }^{1} \mathrm{H}$ NMR: -11.75 (t, hydride, $J=19.5$ $\mathrm{Hz}), 3.58\left(\mathrm{NH}_{2}\right), 6.77(\mathrm{~s}, 1 \mathrm{H}), 6.98-7.03\left(2 \mathrm{H}^{*}\right), 7.07$ (s, 1H), 7.12$7.65\left(2 \mathrm{PPh}_{3}\right)$. Anal. Calcd for 7-NO ${ }_{2}$ : C, 62.12; H, 4.35; N, 6.59. Found: C, 62.31; H, 4.38; N, 6.61. ${ }^{1} \mathrm{H}$ NMR: -11.15 (t, hydride, $J=18.0 \mathrm{~Hz}), 4.90\left(\mathrm{NH}_{2}\right), 6.81(\mathrm{~d}, 1 \mathrm{H}, J=6.2 \mathrm{~Hz}), 6.99(\mathrm{~s}, 1 \mathrm{H})$, $7.20-7.61\left(2 \mathrm{PPh}_{3}\right), 7.90(\mathrm{~s}, 1 \mathrm{H}), 8.01(\mathrm{~d}, 1 \mathrm{H}, J=6.2 \mathrm{~Hz})$.

(vi) 8-H. Benzaldehyde thiosemicarbazone $(22 \mathrm{mg}, 0.12 \mathrm{mmol})$ was dissolved in ethanol $(40 \mathrm{~mL})$. Then, $\left[\mathrm{Rh}\left(\mathrm{PPh}_{3}\right)_{3} \mathrm{Cl}\right](100 \mathrm{mg}$, $0.11 \mathrm{mmol}$ ) was added, and the solution was heated at reflux for 7 $\mathrm{h}$ to yield a yellow solution. Evaporation of this solution gave a yellowish-orange solid, which was subjected to purification by thinlayer chromatography on a silica plate with 10:1 benzene/acetonitrile as the eluant (Caution! Benzene is carcinogenic.); a yellow band separated, which was extracted with acetonitrile, and evaporation of this extract gave $\mathbf{8 - H}$ as a crystalline yellow solid. Yield: $60 \%$. Anal. Calcd for 8-H: C, 62.90; H, 4.41; N, 5.00. Found: C, 63.00; $\mathrm{H}, 4.38$; N, 5.05. ${ }^{1} \mathrm{H}$ NMR: $4.34\left(\mathrm{NH}_{2}\right), 6.53(\mathrm{t}, 1 \mathrm{H}, J=7.6 \mathrm{~Hz})$, $6.63(\mathrm{~s}, 1 \mathrm{H}), 6.80(\mathrm{t}, 1 \mathrm{H}, J=7.2 \mathrm{~Hz}), 6.96(\mathrm{~d}, 1 \mathrm{H}, J=7.4 \mathrm{~Hz})$, $7.13-7.61\left(2 \mathrm{PPh}_{3}\right)$.

(vii) $\mathbf{8}-\mathrm{OCH}_{3}, \mathbf{8}-\mathrm{CH}_{3}, \mathbf{8 - C l}$, and $\mathbf{8}-\mathrm{NO}_{2}$. These four complexes were prepared by following the same procedure as described above using the respective para-substituted benzaldehyde thiosemicarbazone instead of benzaldehyde thiosemicarbazone. Yields varied in the range of $60-80 \%$.

Anal. Calcd for 8- $\mathbf{O C H}_{3}$ : C, 62.11; H, 4.49; N, 4.83. Found: C, 62.45; H, 4.53; N, 4.88. ${ }^{1} \mathrm{H}$ NMR: $3.42\left(\mathrm{OCH}_{3}\right), 4.33\left(\mathrm{NH}_{2}\right)$, $6.46(\mathrm{~d}, 1 \mathrm{H}, J=8.3 \mathrm{~Hz}), 6.69(\mathrm{~s}, 1 \mathrm{H}), 6.99(\mathrm{~s}, 1 \mathrm{H}), 7.08(\mathrm{~d}, 1 \mathrm{H}$, $J=8.4 \mathrm{~Hz}), 7.15-7.56\left(2 \mathrm{PPh}_{3}\right)$. Anal. Calcd for 8-CH $\mathbf{C H}_{3}$ C, 63.28; H, 4.57; N, 4.92. Found: C, 64.00; H, 4.49; N, 4.92. ${ }^{1} \mathrm{H}$ NMR: $1.90\left(\mathrm{CH}_{3}\right), 4.39\left(\mathrm{NH}_{2}\right), 6.59(\mathrm{~d}, 1 \mathrm{H}, J=8.5 \mathrm{~Hz}), 6.61(\mathrm{~s}, 1 \mathrm{H})$, $6.86(\mathrm{~d}, 1 \mathrm{H}, J=7.5 \mathrm{~Hz}), 6.93(\mathrm{~s}, 1 \mathrm{H}), 7.14-7.57\left(2 \mathrm{PPh}_{3}\right)$. Anal. Calcd for 8-Cl: C, 60.42; H, 4.12; N, 4.81. Found: C, 61.01; H, 4.15; N, 4.79. ${ }^{1} \mathrm{H}$ NMR: $4.39\left(\mathrm{NH}_{2}\right), 6.75(\mathrm{~d}, 1 \mathrm{H}, J=8.0 \mathrm{~Hz})$, $6.87(\mathrm{~d}, 1 \mathrm{H}, J=8.0 \mathrm{~Hz}), 7.12(\mathrm{~s}, 1 \mathrm{H}), 7.35(\mathrm{~s}, 1 \mathrm{H}), 7.17-7.57$ $\left(2 \mathrm{PPh}_{3}\right)$. Anal. Calcd for 8-NO $\mathbf{N O}_{2}$ C, 59.70; H, 4.07; N, 6.33. Found: C, 59.23; H, 3.99; N, 6.37. ${ }^{1} \mathrm{H}$ NMR: $4.87\left(\mathrm{NH}_{2}\right), 7.02(\mathrm{~d}$, $1 \mathrm{H}, J=8.2 \mathrm{~Hz}), 7.30(\mathrm{~d}, 1 \mathrm{H}, J=7.0 \mathrm{~Hz}), 7.34(\mathrm{~s}, 1 \mathrm{H}), 7.17-$ $7.61\left(2 \mathrm{PPh}_{3}\right), 8.08(\mathrm{~s}, 1 \mathrm{H})$.

Physical Measurements. Microanalyses (C, H, N) were performed using a Heraeus Carlo Erba 1108 elemental analyzer. IR spectra were obtained on a Shimadzu FTIR-8300 spectrometer with samples prepared as $\mathrm{KBr}$ pellets. Electronic spectra were recorded on a JASCO V-570 spectrophotometer. Magnetic susceptibilities were measured using a PAR 155 vibrating sample magnetometer fitted with a Walker Scientific L75FBAL magnet. ${ }^{1} \mathrm{H}$ NMR spectra were recorded in $\mathrm{CDCl}_{3}$ solution on a Bruker Avance DPX 300 NMR spectrometer using TMS as the internal standard. Electrochemical measurements were made using a $\mathrm{CH}$ Instruments model $600 \mathrm{~A}$ electrochemical analyzer. A platinum disk working electrode, a platinum wire auxiliary electrode, and an aqueous saturated calomel reference electrode (SCE) were used in a three-electrode configuration. All electrochemical experiments were performed under a dinitrogen atmosphere. All electrochemical data were collected at $298 \mathrm{~K}$ and are uncorrected for junction potentials.

Crystallography. Single crystals of $\mathbf{6 - C l} \cdot \mathrm{CH}_{3} \mathrm{CN} \cdot \mathrm{H}_{2} \mathrm{O}$ and 7- $\mathrm{NO}_{2} \cdot 0.5 \mathrm{CH}_{3} \mathrm{CN}$ were grown by slow evaporation of acetonitrile solutions of the respective complexes. Single crystals of 8-Cl were obtained by slow diffusion of hexane into a dichloromethane solution of the complex. Selected crystal data and data collection parameters are reported in Table 1. Data on the crystals of the 
Table 1. Crystallographic Data for 6-Cl, 7- $\mathrm{NO}_{2}$, and 8-Cl

\begin{tabular}{|c|c|c|c|}
\hline & $6-\mathrm{Cl} \cdot \mathrm{CH}_{3} \mathrm{CN} \cdot \mathrm{H}_{2} \mathrm{O}$ & $7-\mathrm{NO}_{2} \cdot 0.5 \mathrm{CH}_{3} \mathrm{CN}$ & $8-\mathrm{Cl}$ \\
\hline empirical formula & $\mathrm{C}_{46} \mathrm{H}_{42} \mathrm{ClN}_{4} \mathrm{O}_{3} \mathrm{P}_{2} \mathrm{SRh}$ & $\mathrm{C}_{45} \mathrm{H}_{38.50} \mathrm{~N}_{4.50} \mathrm{O}_{2} \mathrm{P}_{2} \mathrm{SR} \mathrm{h}$ & $\mathrm{C}_{44} \mathrm{H}_{36} \mathrm{Cl}_{2} \mathrm{~N}_{3} \mathrm{P}_{2} \mathrm{RhS}$ \\
\hline$f_{\mathrm{w}}$ & 931.20 & 871.21 & 874.57 \\
\hline space group & monoclinic, $C 2 / c$ & triclinic, $P \overline{\mathbf{1}}$ & monoclinic, $C 2 / c$ \\
\hline$a, \AA$ & $40.8268(9)$ & $13.611(2)$ & $23.8312(13)$ \\
\hline$b, \AA$ & $10.2807(2)$ & $16.1666(3)$ & $17.1846(10)$ \\
\hline$c, \AA$ & $23.8179(5)$ & $19.4501(18)$ & $23.2866(12)$ \\
\hline $\mathrm{a}, \mathbf{d e g}$ & 90 & $94.918(11)$ & 90 \\
\hline$b$, deg & $120.13(1)$ & $101.705(9)$ & $120.433(2)$ \\
\hline g, deg & 90 & $101.074(18)$ & 90 \\
\hline$V, \AA^{3}$ & $8646.5(3)$ & $4078.1(12)$ & $8222.6(8)$ \\
\hline$Z$ & 8 & 4 & 8 \\
\hline $1, \AA ̊ \AA$ & 0.71073 & 0.71073 & 0.71073 \\
\hline crystal size, $\mathrm{mm}$ & $0.25 \times 0.20 \times 0.10$ & $0.41 \times 0.26 \times 0.22$ & $0.12 \times 0.08 \times 0.06$ \\
\hline$T, \mathrm{~K}$ & $295(2)$ & $299(2)$ & $295(2)$ \\
\hline $\mathrm{m}, \mathbf{m m}^{-1}$ & 0.625 & 0.592 & 0.709 \\
\hline $\mathrm{R} 1^{a}$ & 0.0371 & 0.0517 & 0.709 \\
\hline $\mathrm{wR} 2^{b}$ & 0.0860 & 0.1124 & 0.2876 \\
\hline $\mathrm{GOF}^{c}$ & 1.016 & 1.050 & 1.016 \\
\hline
\end{tabular}

${ }^{a} \mathrm{R} 1=\sum|| F_{\mathrm{o}}|-| F_{\mathrm{c}}|| \sum\left|F_{\mathrm{o}}\right| \cdot{ }^{b} \mathrm{wR} 2=\left[\sum\left[w\left(F_{\mathrm{o}}{ }^{2}-F_{\mathrm{c}}{ }^{2}\right)^{2}\right] / \sum\left[\mathrm{w}\left(F_{\mathrm{o}}{ }^{2}\right)^{2}\right]\right]^{1 / 2} \cdot{ }^{c} \mathrm{GOF}=\left[\sum\left[w\left(F_{\mathrm{o}}{ }^{2}-F_{\mathrm{c}}{ }^{2}\right)^{2}\right] /(M-N)\right]^{1 / 2}$, where $M$ is the number of reflections and $N$ is the number of parameters refined.

6- $\mathbf{C l} \cdot \mathrm{CH}_{3} \mathrm{CN} \cdot \mathrm{H}_{2} \mathrm{O}$ and 8-Cl complexes were collected on a Bruker SMART CCD diffractometer. Data on the crystal of the 7- $\mathrm{NO}_{2} \cdot 0.5 \mathrm{CH}_{3} \mathrm{CN}$ complex were collected on an Enraf-Nonius CAD-4 diffractometer. X-ray data reduction, structure solution, and refinement were done using the SHELXS-97 and SHELXL-97 packages. ${ }^{11}$ The structures were solved by direct methods.

\section{Results and Discussion}

Reaction of the benzaldehyde thiosemicarbazones 1 with $\left[\mathrm{Rh}\left(\mathrm{PPh}_{3}\right)_{3} \mathrm{Cl}\right]$ has been first carried out in refluxing ethanol in the presence of triethylamine. Whereas a yellow complex is uniformly obtained as the only product from the reactions with the four thiosemicarbazones 1 with $\mathrm{R}=\mathrm{OCH}_{3}, \mathrm{CH}_{3}$, $\mathrm{H}$, and $\mathrm{Cl}$, reaction with the para-nitrobezaldehyde thiosemicarbazone $\left(1, \mathrm{R}=\mathrm{NO}_{2}\right)$ affords two complexes: a pinkishred and a red complex. On the basis of its composition and properties (vide infra), the pinkish-red complex was determined to belong to the family of the yellow complexes. The red complex, however, was found to be different, both in composition and in properties, than the yellow complexes.

${ }^{1} \mathrm{H}$ NMR spectra of the yellow ${ }^{12}$ complexes show, in addition to signals for the coordinated thiosemicarbazone, broad signals corresponding to two $\mathrm{PPh}_{3}$ ligands and a distinct triplet near $-11.5 \mathrm{ppm}$ indicating the presence of a coordinated hydride. The triplet nature of the hydride signal further indicates that the two $\mathrm{PPh}_{3}$ ligands are magnetically equivalent in these complexes. However, splitting of the hydride signal due to coupling with the rhodium nucleus ( $I$ $=1 / 2$ ) was not observed. The preliminary characterization data (microanalytical and spectroscopic) of these complexes, although gave some idea of their composition, failed to indicate any definite formulation for them. The identities of these complexes were revealed by structure determination of a representative member of this family by X-ray crystallography. The structure (Figure 1) shows that, during the

(11) Sheldrick, G. M. SHELXS-97 and SHELXL-97, Fortran Programs for Crystal Structure Solution and Refinement; University of Göttingen, Göttingen, Germany, 1997.

(12) Pinkish-red for the complex obtained from the reaction with the paranitrobezaldehyde thiosemicarbazone $\left(1, \mathrm{R}=\mathrm{NO}_{2}\right)$. course of the synthetic reaction, the thiosemicarbazone undergoes oxidation at the sulfur center whereby it is converted into sulfone, and the transformed thiosemicarbazone is coordinated to rhodium as a dianionic tridentate $\mathrm{C}, \mathrm{N}, \mathrm{S}$ donor. Two triphenylphosphines and a hydride are also coordinated to rhodium. The $\mathrm{HCNP}_{2} \mathrm{~S}$ coordination sphere around rhodium is distorted octahedral in nature, which is reflected in the bond parameters (Table 2) around rhodium. The oxidized thiosemicarbazone, the rhodium, and the hydride constitute an equatorial plane with the metal at the center, and the two $\mathrm{PPh}_{3}$ ligands take up the axial positions and, hence, are mutually trans. The $\mathrm{Rh}-\mathrm{C}, \mathrm{Rh}-$ $\mathrm{N}, \mathrm{Rh}-\mathrm{P}$, and $\mathrm{Rh}-\mathrm{S}$ distances are quite normal. ${ }^{3 \mathrm{a}, 7}$ However, the $\mathrm{Rh}-\mathrm{H}$ bond is rather shorter than usual, ${ }^{13}$ which can be attributed to the enhanced electropositive nature of rhodium due to its link to the sulfone fragment. The $\mathrm{C}-\mathrm{S}, \mathrm{S}-\mathrm{O}$, and $\mathrm{C}-\mathrm{N}$ distances in the coordinated thiosemicarbazone are

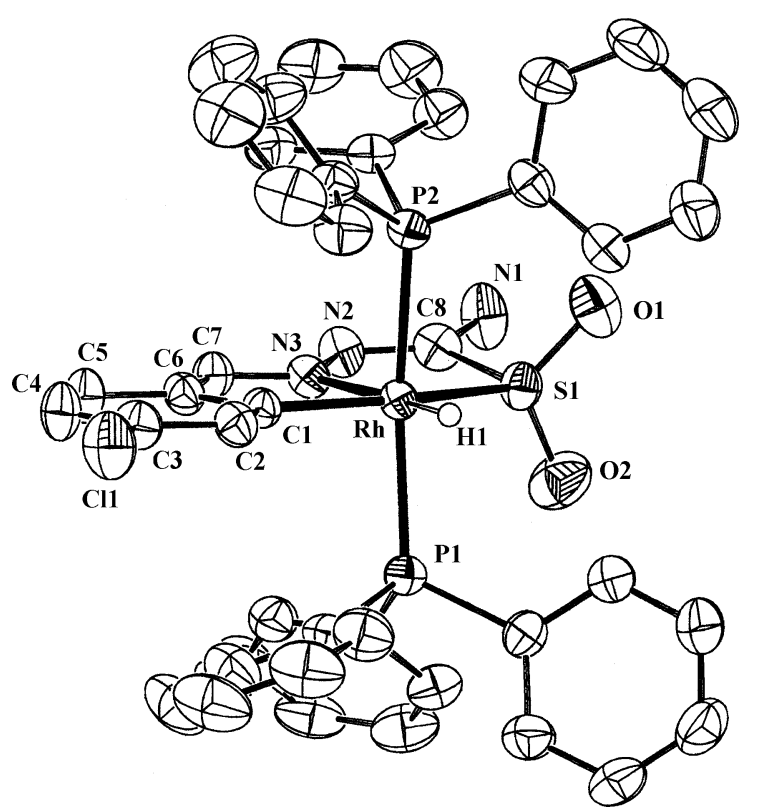

Figure 1. View of the 6-Cl complex, with thermal ellipsoids drawn at the $50 \%$ probability level. 
Acharyya et al.

Table 2. Selected Bond Distances and Bond Angles for 6-Cl, 7--NO

\begin{tabular}{|c|c|c|c|c|c|}
\hline \multicolumn{2}{|l|}{ 6- $\mathrm{Cl} \cdot \mathrm{CH}_{3} \mathrm{CN} \cdot \mathrm{H}_{2} \mathrm{O}$} & \multicolumn{2}{|l|}{$7-\mathrm{NO}_{2} \cdot 0.5 \mathrm{CH}_{3} \mathrm{CN}$} & \multicolumn{2}{|l|}{ 8-Cl } \\
\hline \multicolumn{6}{|c|}{ Bond Distances $(\AA)$} \\
\hline $\mathrm{Rh}-\mathrm{H}(1)$ & $1.437(4)$ & $\mathrm{Rh}(1)-\mathrm{H}(1 \mathrm{H})$ & $1.57(6)$ & $\mathrm{Rh}-\mathrm{Cl}(1)$ & $2.385(3)$ \\
\hline $\mathrm{Rh}-\mathrm{P}(1)$ & $2.3380(8)$ & $\mathrm{Rh}(1)-\mathrm{P}(1)$ & $2.3218(16)$ & $\mathrm{Rh}-\mathrm{P}(1)$ & $2.379(3)$ \\
\hline $\mathrm{Rh}-\mathrm{P}(2)$ & $2.3483(8)$ & $\mathrm{Rh}(1)-\mathrm{P}(2)$ & $2.3041(15)$ & $\mathrm{Rh}-\mathrm{P}(2)$ & $2.371(3)$ \\
\hline $\mathrm{Rh}-\mathrm{N}(3)$ & $2.096(2)$ & $\mathrm{Rh}(1)-\mathrm{N}(2)$ & $2.074(4)$ & $\mathrm{Rh}-\mathrm{N}(3)$ & $1.990(10)$ \\
\hline $\mathrm{Rh}-\mathrm{C}(1)$ & $2.039(3)$ & $\mathrm{Rh}(1)-\mathrm{C}(39)$ & $2.038(5)$ & $\mathrm{Rh}-\mathrm{C}(8)$ & $2.044(11)$ \\
\hline $\mathrm{Rh}-\mathrm{S}(1)$ & $2.3366(8)$ & $\mathrm{Rh}(1)-\mathrm{S}(1)$ & $2.4116(15)$ & $\mathrm{Rh}-\mathrm{S}(1)$ & $2.450(3)$ \\
\hline$C(7)-N(3)$ & $1.301(4)$ & $\mathrm{C}(43)-\mathrm{N}(2)$ & $1.288(7)$ & $\mathrm{C}(2)-\mathrm{N}(3)$ & $1.251(14)$ \\
\hline $\mathrm{N}(2)-\mathrm{N}(3)$ & $1.385(3)$ & $\mathrm{N}(2)-\mathrm{N}(3)$ & $1.370(6)$ & $\mathrm{N}(2)-\mathrm{N}(3)$ & $1.362(14)$ \\
\hline $\mathrm{C}(8)-\mathrm{N}(2)$ & $1.298(4)$ & $\mathrm{C}(44)-\mathrm{N}(3)$ & $1.3191(7)$ & $\mathrm{C}(1)-\mathrm{N}(2)$ & $1.337(16)$ \\
\hline $\mathrm{C}(8)-\mathrm{N}(1)$ & $1.326(4)$ & $\mathrm{C}(44)-\mathrm{N}(4)$ & $1.3421(7)$ & $\mathrm{C}(1)-\mathrm{N}(1)$ & $1.379(15)$ \\
\hline$C(8)-S(1)$ & $1.855(3)$ & $\mathrm{C}(44)-\mathrm{S}(1)$ & $1.743(6)$ & $C(1)-S(1)$ & $1.708(14)$ \\
\hline $\mathrm{S}(1)-\mathrm{O}(1)$ & $1.461(2)$ & & & & \\
\hline $\mathrm{S}(1)-\mathrm{O}(2)$ & $1.465(2)$ & & & & \\
\hline \multicolumn{6}{|c|}{ Bond Angles (deg) } \\
\hline $\mathrm{H}(1)-\mathrm{Rh}-\mathrm{N}(3)$ & 172.61(7) & $\mathrm{H}(1 \mathrm{H})-\mathrm{Rh}(1)-\mathrm{N}(2)$ & $176(2)$ & $\mathrm{N}(3)-\mathrm{Rh}-\mathrm{Cl}(1)$ & 176.1(3) \\
\hline $\mathrm{C}(1)-\mathrm{Rh}-\mathrm{S}(1)$ & $160.14(9)$ & $\mathrm{C}(39)-\mathrm{Rh}(1)-\mathrm{S}(1)$ & $159.99(17)$ & $\mathrm{C}(8)-\mathrm{Rh}-\mathrm{S}(1)$ & $162.2(3)$ \\
\hline $\mathrm{P}(1)-\mathrm{Rh}-\mathrm{P}(2)$ & $165.40(3)$ & $\mathrm{P}(1)-\mathrm{Rh}(1)-\mathrm{P}(2)$ & $169.23(6)$ & $\mathrm{P}(1)-\mathrm{Rh}-\mathrm{P}(2)$ & $179.56(10)$ \\
\hline $\mathrm{C}(1)-\mathrm{Rh}-\mathrm{N}(3)$ & $79.73(10)$ & $\mathrm{C}(39)-\mathrm{Rh}(1)-\mathrm{N}(2)$ & $80.2(2)$ & $\mathrm{C}(8)-\mathrm{Rh}-\mathrm{N}(3)$ & $81.1(4)$ \\
\hline $\mathrm{N}(3)-\mathrm{Rh}-\mathrm{S}(1)$ & $80.46(7)$ & $\mathrm{N}(2)-\mathrm{Rh}(1)-\mathrm{S}(1)$ & $79.91(12)$ & $\mathrm{N}(3)-\mathrm{Rh}-\mathrm{S}(1)$ & $81.1(3)$ \\
\hline $\mathrm{O}(1)-\mathrm{S}(1)-\mathrm{O}(2)$ & $112.74(16)$ & & & & \\
\hline
\end{tabular}

consistent with its bonding description. As all the five complexes in this family (6, see Chart 1) were prepared similarly and display similar spectral and electrochemical properties (vide infra), the other four $\mathbf{6}-\mathbf{R}(\mathrm{R} \neq \mathrm{Cl})$ complexes are assumed to have a structure similar to that of $\mathbf{6 - C l}$.

The ${ }^{1} \mathrm{H}$ NMR spectrum of the red complex, obtained as a second product only from the reaction of para-nitrobenzaldehyde thiosemicarbazone with $\left[\mathrm{Rh}\left(\mathrm{PPh}_{3}\right)_{3} \mathrm{Cl}\right]$, was found to be quite similar to that of $\mathbf{6}-\mathbf{N O}_{2}$. However, significant differences were found in the infrared spectra of these two complexes (vide infra). For an unambiguous characterization of the red complex, its structure was also determined by X-ray crystallography. The structure (Figure 2) shows that, in this complex, the thiosemicarbazone does not undergo any oxidation and is coordinated to rhodium as a tridentate C,N,S donor. Two triphenylphosphines and a hydride are also coordinated to rhodium as before. In this red complex

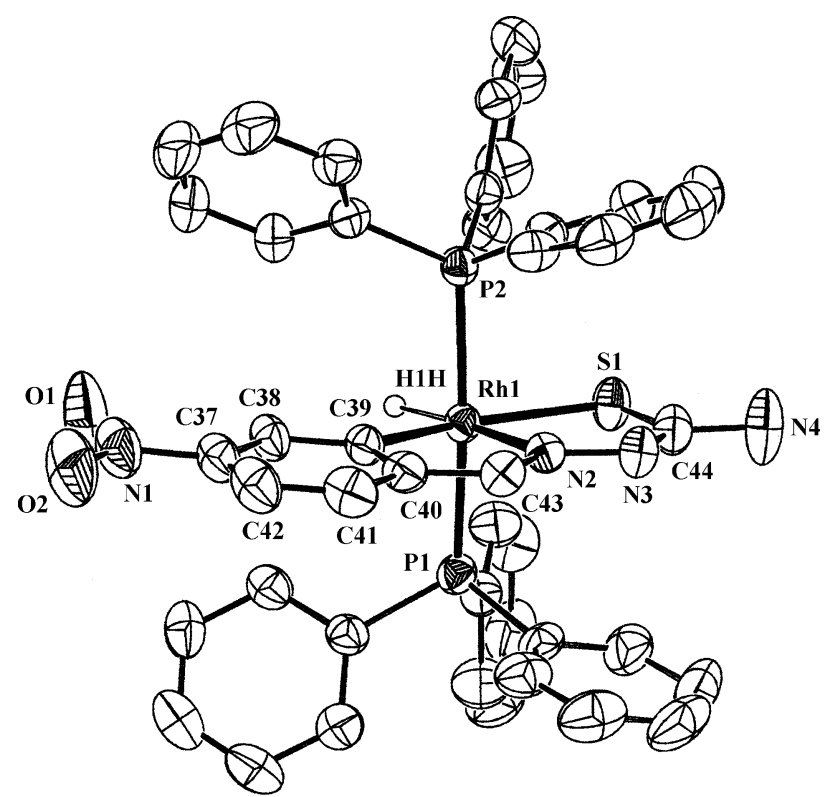

Figure 2. View of the 7-NO $\mathbf{N}_{2}$ complex, with thermal ellipsoids drawn at the $50 \%$ probability level.
(7-NO $\mathrm{N}_{2}$, Chart 2), the $\mathrm{Rh}-\mathrm{H}$ length is found to be quite normal (Table 2) ${ }^{14}$ The $\mathrm{Rh}-\mathrm{S}$ distance is significantly longer in this complex than in $\mathbf{6 - C l}$, which can be attributed to the different oxidation states of sulfur in the two complexes. ${ }^{15}$ The other bond distances in $\mathbf{7 - \mathbf { N O } _ { 2 }}$ are comparable to those observed in 6-Cl.

The mechanism of the observed oxidation at the sulfur center is not completely clear to us. However, the speculated sequences shown in Scheme 1 seem probable. In the initial step, dissociation of the acidic hydrogen from the benzaldehyde thiosemicabazones $\mathbf{1}$ takes place in the presence of the base. Reaction of the resulting anionic ligands with [Rh$\left(\mathrm{PPh}_{3}\right)_{3} \mathrm{Cl}$ ] leads to the formation of complexes 7 via oxidative insertion of rhodium into the phenyl $\mathrm{C}-\mathrm{H}$ bond. The presence of the coordinated hydride increases the electron density on the sulfur center, which allows its direct oxidation by molecular oxygen to afford the final product (6). Similar oxidation of coordinated thiolate sulfur to corresponding sulfinate form by molecular oxygen has precedent in the literature. ${ }^{16}$ The intermediate complex 7 could be isolated only in the case of $\mathrm{R}=\mathrm{NO}_{2}$. In ethanolic solution, 7- $\mathbf{N O}_{2}$ was observed to undergo very slow oxidation in the presence of air to produce the corresponding sulfone complex $\left(\mathbf{6}-\mathrm{NO}_{2}\right)$. The strong electron-withdrawing character of this substituent appears to inhibit further oxidation of

(13) (a) Circu, V.; Fernandez, M. A.; Carlton, L. Inorg. Chem. 2002, 41, 3859. (b) Evans, D. R.; Huang, M. S.; Seganish, W. M.; Chege, E. W.; Lam, Y. F.; Feltinger, J. C.; Williams, T. L. Inorg. Chem. 2002, 41, 2633. (c) Huang, J.; Stevens, E. D.; Nolan, S. P. Organometallics 2000, 19, 1194. (d) Sjovall, S.; Svensson, P. H.; Anderson, C. Organometallics 1999, 18, 5412.

(14) (a) Rifat, A.; Patmore, N. J.; Mahon, M. F.; Weller, A. S. Organometallics 2002, 21, 2856. (b) Ball, R. G.; James, B. R.; Mahajan, D.; Trotter, J. Inorg. Chem. 1981, 20, 254.

(15) Lee, C. M.; Hsieh, C. H.; Dutta, A.; Lee, G. H.; Liaw, W. F. J. Am. Chem. Soc. 2003, 125, 11492.

(16) (a) Cocker, T. M.; Bachman, R. E. Chem. Commun. 1999, 875. (b) Mirza, S. A.; Pressler, M. A.; Kumar, M.; Day, R. O.; Maroney, M. J. Inorg. Chem. 1993, 32, 977. (c) Farmer, P. J.; Solouki, T.; Mills, D. K.; Soma, T.; Russel, D. H.; Reibenspies, J. H.; Darensbourg, M. Y. J. Am. Chem. Soc. 1992, 114, 4601. (d) Kumar, M.; Colpas, G. J.; Day, R. O.; Maroney, M. J. J. Am. Chem. Soc. 1989, 111, 8323. (e) Nicholson, T.; Zubieta, J. Inorg. Chem. 1987, 26, 2094. 
Scheme 1. Probable Steps for the Formation of Complexes 6<smiles>[R]c1ccc(/C=N/NC(N)=S)cc1</smiles>
and industrial applications of such reactions. ${ }^{17}$
7-NO $\mathrm{N}_{2}$. It should be mentioned in this context that activation of molecular oxygen by transition metal complexes is of significant importance, with particular reference to biological

The above speculation, that rhodium undergoes an oxidative insertion into the acidic phenyl $\mathrm{C}-\mathrm{H}$ bond affording the $\mathrm{C}-\mathrm{Rh}^{\mathrm{III}}-\mathrm{H}$ fragment, points to the possibility of similar and more facile activation of the potentially acidic $\mathrm{S}-\mathrm{H}$ bond of the thiosemicarbazone (in the tautomeric thiol form), provided that the $\mathrm{S}-\mathrm{H}$ bond remains intact prior to its reaction with the rhodium(I) center in $\left[\mathrm{Rh}\left(\mathrm{PPh}_{3}\right)_{3} \mathrm{Cl}\right]$. To clarify this issue, reactions between $\left[\mathrm{Rh}\left(\mathrm{PPh}_{3}\right)_{3} \mathrm{Cl}\right]$ and the benzaldehyde thiosemicarbazones $\mathbf{1}$ were also carried out as before, but in the absence of any base. Each of these reactions afforded a yellow ${ }^{18}$ complex. Aside from the absence of any hydride signal, the ${ }^{1} \mathrm{H}$ NMR spectra of these complexes are

(17) (a) Advances in Catalytic Activation of Dioxygen by Metal Complexes; Simandi, L. I., Ed.; Hungarian Academy of Sciences: Budapest, Hungary, 2002. (b) Detlef, S.; Helmet, S. Essays Contemp. Chem. 2001, 131. (c) Que, L., Jr.; Ho, R. Y. N. Chem. Rev. 1996, 96, 2607. (d) Fox, S.; Karlin, K. D. In Active Oxygen in Biochemistry; Valentine, J. S., Foote, C. S., Greenberg, A., Liebman, J. F., Eds.; Blackie Academic \& Professional: London, 1995; pp 188-232. (e) Karlin, K. D.; Tyeklar, Z. In Models in Inorganic Biochemistry; Eichhorn, G. L., Marzilli, L. G., Eds.; PTR Prentice Hall: Englewood Cliffs, NJ, 1994. (f) Klotz, I. M.; Kurtz, D. M. Chem. Rev. 1994, 94, 567. (g) Sheldon, R. A.; Kochi, J. K. Metal Catalyzed Oxidations of Organic Compounds; Academic Press: New York, 1981.

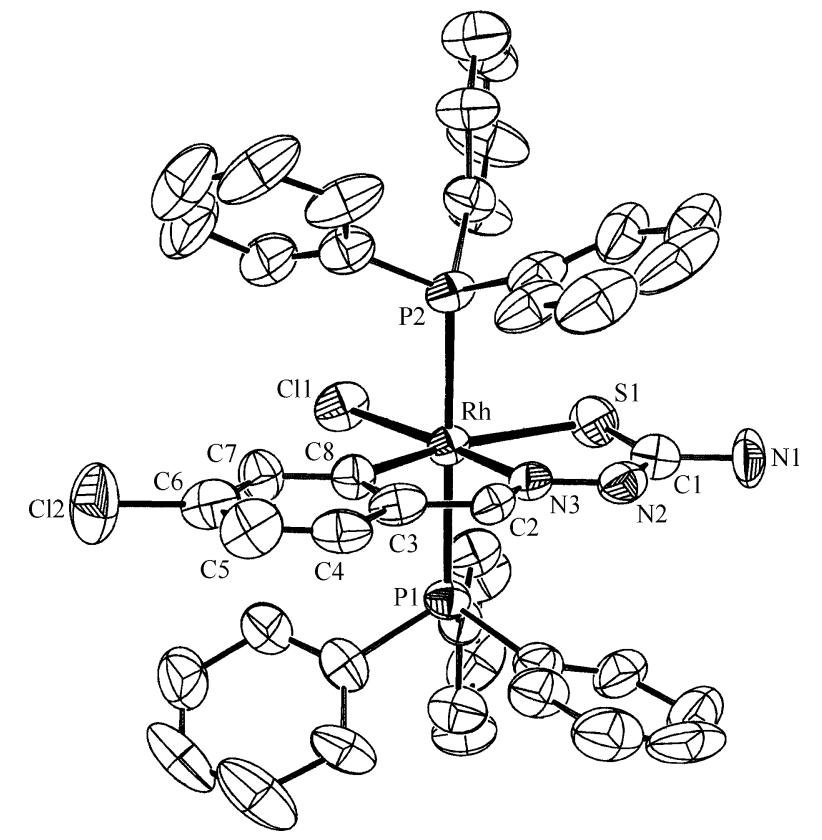

Figure 3. View of the 8-Cl complex, with thermal ellipsoids drawn at the $50 \%$ probability level.

Scheme 2. Probable Steps for the Formation of Complexes 8<smiles>[R]c1ccc(/C=N/NC(N)=S)cc1/C=N/N=C(/N)S</smiles>

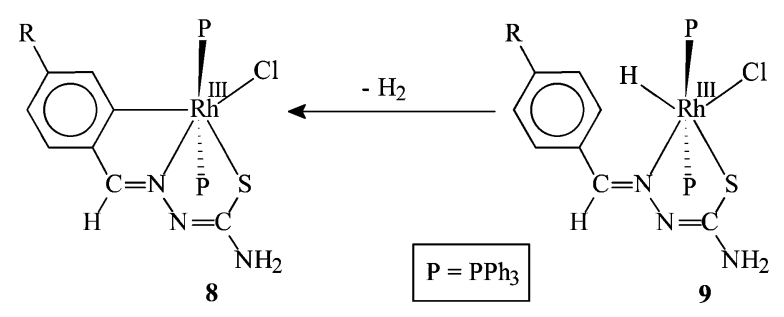

qualitatively similar to those of the complexes 6 . The identities of this new group of complexes were unveiled by structural characterization of a representative member by X-ray crystallography. The structure (Figure 3) shows that the thiosemicarbazone is bound to rhodium in the tridentate $\mathrm{C}, \mathrm{N}, \mathrm{S}$ fashion and that two $\mathrm{PPh}_{3}$ ligands and a chloride are also coordinated to the metal center. The $\mathrm{Rh}-\mathrm{Cl}$ distance is normal, ${ }^{3 \mathrm{a}, 7}$ and the other structural features are similar to those observed in $\mathbf{7 - \mathbf { N O } _ { 2 }}$ (Table 2). As all five complexes in this group (8, Chart 1) display similar spectral and electrochemical properties (vide infra), the other four 8-R $(\mathrm{R} \neq \mathrm{Cl})$ complexes are assumed to have structures similar to that of $\mathbf{8 - C l}$.

The speculated sequences behind the formation of the complexes $\mathbf{8}$ are shown in Scheme 2. In the absence of any base, the $\mathrm{S}-\mathrm{H}$ bond in the thiolate tautomer seems to play 
Table 3. Electronic Spectral and Cyclic Voltammetric Data of the Complexes

\begin{tabular}{|c|c|c|}
\hline compd & $\begin{array}{l}\text { electronic spectral data }{ }^{a} \\
\lambda_{\max }, \mathbf{n m}\left(\epsilon, \mathbf{M}^{-1} \mathbf{c m}^{-1}\right)\end{array}$ & $\begin{array}{l}\text { cyclic voltammetric } \\
\text { data }^{b} E, \mathrm{~V}\end{array}$ \\
\hline $6-\mathrm{OCH}_{3}$ & 404 (3700), 288 (18500), 240 (24700) & $0.64,^{c} 1.07,{ }^{c}-1.18^{d}$ \\
\hline $6-\mathrm{CH}_{3}$ & $400(2700), 286(14200), 234(20400)$ & $0.68,^{c} 1.12,^{c-1} 19^{d}$ \\
\hline 6-H & $406(2500), 288(14400), 234(30500)$ & $0.72,^{c} 0.93{ }^{c}-1.19^{d}$ \\
\hline 6-Cl & $368(2800), 292(11000), 234(23000)$ & $0.77,^{c} 1.32,^{c-1} 1.14^{d}$ \\
\hline $6-\mathrm{NO}_{2}$ & $510(9100), 360(14000)$ & $0.84,{ }^{c} 1.13,{ }^{c}-1.19^{d}$ \\
\hline $7-\mathrm{NO}_{2}$ & $510(5200), 354(9100), 286(17500)$ & $0.88,^{c} 1.13,^{c}-1.3^{d}$ \\
\hline $8-\mathrm{OCH}_{3}$ & $422(5200), 308(22800), 274(25400)$ & $0.72^{e}(66),{ }^{f} 1.23,^{c}-1.07^{d}$ \\
\hline $8-\mathrm{CH}_{3}$ & $426(5200), 310(27300), 274(31000)$ & $0.81^{e}(73){ }^{f} 1.39{ }^{c}-1.06^{d}$ \\
\hline 8-H & $424(3400), 312(21700), 272(24500)$ & $0.86^{e}(76){ }^{f} 1.42,^{c}-1.23^{d}$ \\
\hline 8-Cl & $426(3800), 304(22800), 272(21700)$ & $0.93^{e}(82)^{f} 1.599^{c}-1.32^{d}$ \\
\hline 8-NO2 & $508(4900), 310(25400), 272(23000)$ & $1.07^{e}(76),{ }^{f} 1.74,^{c}-1.23^{d}$ \\
\hline
\end{tabular}

${ }^{a}$ In dichloromethane solution. ${ }^{b}$ Solvent, 1:9 dichloromethane/acetonitrile; supporting electrolyte, TBAP; reference electrode, SCE; scan rate, $50 \mathrm{mV} \mathrm{s}{ }^{-1}$. ${ }^{c} E_{\mathrm{pa}}$ value, where $E_{\mathrm{pa}}$ is the anodic peak potential. ${ }^{d} E_{\mathrm{pc}}$ value, where $E_{\mathrm{pc}}$ is the cathodic peak potential. ${ }^{e} E_{1 / 2}=0.5\left(E_{\mathrm{pa}}+E_{\mathrm{pc}}\right) .{ }^{f} \Delta E_{\mathrm{p}}=E_{\mathrm{pa}}-E_{\mathrm{pc}}$.

a very important role. In the initial step, the thiosemicarbazones bind to the metal center in $\left[\mathrm{Rh}\left(\mathrm{PPh}_{3}\right)_{3} \mathrm{Cl}\right]$, via oxidative insertion of rhodium into this $\mathrm{S}-\mathrm{H}$ bond and simultaneous dissociation of one triphenylphospine, generating complexes 9 as the reactive intermediates, which then undergo cyclometalation via elimination of $\mathrm{H}_{2}$ to afford complexes 8 .

The infrared spectra of all five 6-R complexes are similar. Each complex shows strong vibrations near 520, 695, and $745 \mathrm{~cm}^{-1}$, indicating the presence of coordinated $\mathrm{PPh}_{3}$ ligands. ${ }^{3,7}$ The $\mathrm{Rh}-\mathrm{H}$ stretch is observed near $1970 \mathrm{~cm}^{-1}$ as a sharp band. ${ }^{19}$ Many new vibrations, compared to the spectrum of $\left[\mathrm{Rh}\left(\mathrm{PPh}_{3}\right)_{3} \mathrm{Cl}\right]$, are observed in the spectra of these 6-R complexes (e.g., near 1157, 1387, 1551, 1568, and $1626 \mathrm{~cm}^{-1}$ ), which are attributable to the coordinated thiosemicarbazone ligand. Of these new vibrations, the strong band near $1157 \mathrm{~cm}^{-1}$ is assigned the $\mathrm{S}=\mathrm{O}$ stretches..$^{15}$ The infrared spectrum of $\mathbf{7 - \mathbf { N O } _ { 2 }}$ is mostly similar to that of 6- $\mathrm{NO}_{2}$, except that the $v(\mathrm{~S}=\mathrm{O})$ vibration was not observed in the former, as expected. Aside from the absence of the $v(\mathrm{Rh}-\mathrm{H})$ and $v(\mathrm{~S}=\mathrm{O})$ stretches, the infrared spectrum of each $\mathbf{8}-\mathbf{R}$ complex is similar to that of the corresponding 6-R complex.

Electronic spectra of all of the complexes, recorded in dichloromethane solution, show intense absorptions in the visible and ultraviolet regions (Table 3 ). The absorptions in the ultraviolet region are attributable to transitions within the ligand orbitals, and those in the visible region are probably due to charge-transfer transitions. For a better understanding of the nature of the transitions in the visible region, qualitative EHMO calculations were performed ${ }^{20}$ on computergenerated models of all of the complexes in which the phenyl rings of the triphenylphosphines were replaced by hydrogens. The results were found to be similar for all of the complexes. ${ }^{21}$ The compositions of selected molecular orbitals (Table S1) and partial MO diagrams of the three representative complexes (Figures S1-S3) are available as Supporting Information. The highest occupied molecular orbital (HOMO) and the next two filled orbitals (HOMO - 1 and HOMO 2) have major contributions from the rhodium $d_{x y}, d_{y z}$, and

(18) Orange complex obtained from the reaction with the para-nitrobezaldehyde thiosemicarbazone $\left(\mathbf{1}, \mathrm{R}=\mathrm{NO}_{2}\right)$.

(19) Fenster, A.; James, B. R.; Cullen, W. R. Inorg. Synth. 1977, 17, 81

(20) (a) Mealli, C.; Proserpio, D. M. CACAO, version 4.0; Firenze, Italy, 1994. (b) Mealli, C.; Proserpio, D. M. J. Chem. Edu. 1990, 67, 399. $\mathrm{d}_{z x}$ orbitals. ${ }^{21}$ These three occupied orbitals can therefore be regarded as the rhodium $t_{2}$ orbitals. The lowest unoccupied molecular orbital (LUMO) has $>80 \%$ contribution from the thiosemicarbazone ligand and is concentrated mostly ( $>49 \%)$ on the azomethine imine $(-\mathrm{HC}=\mathrm{N}-)$ fragment. ${ }^{21} \mathrm{LUMO}$ +1 and LUMO +2 are localized on other parts of the thiosemicarbazone ligand. The lowest-energy absorption in the visible region can therefore be assigned to an allowed chargetransfer transition from the filled rhodium $\mathrm{t}_{2}$ orbital (HOMO) to the vacant $\pi^{*}$ (azomethine imine) orbital of the thiosemicarbazone ligand (LUMO). ${ }^{21}$

The electrochemical properties of all of the complexes were studied in 1:9 dichloromethane/acetonitrile solution (0.1 M TBAP) by cyclic voltammetry. ${ }^{22}$ A selected voltammogram (Figure S4) is available as Supporting Information. Each complex shows two oxidative responses on the positive side of SCE and a reductive response on the negative side (Table 3). In view of the composition of the HOMO, the first oxidative response is assigned to $\mathrm{Rh}(\mathrm{III})-\mathrm{Rh}(\mathrm{IV})$ oxidation. The one-electron nature of this oxidation was verified by comparing its current height with that of the standard ferrocene-ferrocenium couple under identical experimental conditions. This oxidation was found to be

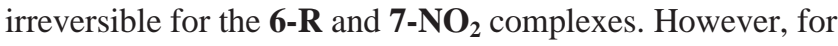
the $\mathbf{8}-\mathbf{R}$ complexes, the same oxidation was observed to be reversible, characterized by a peak-to-peak separation $\left(\Delta E_{\mathrm{p}}\right)$ of $60-70 \mathrm{mV}$ and an anodic peak current $\left(i_{\mathrm{pa}}\right)$ that is equal to the cathodic peak current $\left(i_{\mathrm{pc}}\right)$. The second oxidation is irreversible in nature in all of the complexes and is tentatively assigned to oxidation of the coordinated thiosemicarbazones. All of the complexes show an irreversible reductive response, and with reference to the composition of the LUMO, ${ }^{21}$ the reduction is attributed to reduction of the coordinated thiosemicarbazone. All of the irreversible redox responses show nonstoichiometric currents. Potentials of the redox responses do not show any systematic variation with the nature of the substituent $\mathrm{R}$ in the thiosemicarbazone ligand.

(21) In $\mathbf{8}-\mathrm{NO}_{2}$, the HOMO has a major metal contribution, whereas HOMO -1 has less metal character. In all of the complexes having $\mathrm{R}=$ $\mathrm{NO}_{2}$, the LUMO has a significant contribution from the $\mathrm{NO}_{2}$ group, and LUMO + 1 has considerable azomethine imine character.

(22) A little dichloromethane was necessary to take the complex into solution. Addition of a large excess of acetonitrile was necessary to record the redox responses in proper shape. 


\section{Conclusions}

The present study shows that the benzaldehyde thiosemicarbazones 1 can undergo facile $\mathrm{C}-\mathrm{H}$ activation at one ortho position of the phenyl ring, mediated by $\left[\mathrm{Rh}\left(\mathrm{PPh}_{3}\right)_{3} \mathrm{Cl}\right]$. The present study further demonstrates that, in addition to phenyl $\mathrm{C}-\mathrm{H}$ activation, $\mathrm{S}-\mathrm{H}$ activation or oxidation of the sulfur center can also be brought about by simple manipulation of the experimental conditions.

Acknowledgment. Financial assistance received from the Council of Scientific and Industrial Research, New Delhi, India [Grant 01(1952)/04/EMR-II], is gratefully acknowledged. The authors thank the reviewers for their constructive suggestions, which were very helpful in preparing the revised manuscript. Thanks are due to the RSIC at Central Drug Research Institute, Lucknow, India, for the $\mathrm{C}, \mathrm{H}, \mathrm{N}$ analysis data. R.A. and S.D. thank the Council of Scientific and Industrial Research, New Delhi, India, for their fellowships [Grants 9/96(438)2004-EMR-I and 9/96(410)/2003-EMR-I, respectively].

Supporting Information Available: Partial molecular orbital diagrams of 6-Cl (Figure S1), 7- $\mathbf{N O}_{2}$ (Figure S2), and $\mathbf{8 - \mathbf { C H } _ { 3 }}$ (Figure S3). Cyclic voltammogram of 8-H (Figure S4). Composition of selected molecular orbitals for all the complexes (Table S1). $\mathrm{X}$-ray crystallographic data in CIF format. This material is available free of charge via the Internet at http://pubs.acs.org.

IC050505W 